\title{
Ownership matters: Natural resources property rights and social conflict in Sub-Saharan Africa ${ }^{\text {th }}$
}

\author{
Tim Wegenast*, Gerald Schneider ${ }^{* *}$ \\ University of Konstanz, Department of Politics and Management, Universitatsstraße 10, Box D86, 78464 Konstanz, Germany
}

Keywords:

Natural resources

Ownership

Property rights

Repression

Protests

\begin{abstract}
A B S T R A C T
Empirical tests of the "resource curse" thesis have provided inconclusive evidence for the claim that natural resource abundance increases the risk of social conflict. The present article argues, based on a novel political economy framework and a new data set, that it is important to analyze how states regulate the access to their natural resources to understand the interrelationship between resources and public resistance against resource extraction arrangements. We claim that international rather than state resource ownership fosters the regional protest potential and overshadows the efficiency gains that foreign investment might create. Especially the siphoning of resource rents to international owners instigates resentment among the local population. Distinguishing between private, public, domestic and international ownership arrangements, we assess the effects of natural resources control rights regimes on state repression using new GIS based data on diamond and gold mines as well as oil and gas fields in Sub Sahara Africa. Our multilevel analysis shows that repression as an answer to societal dissent is particularly likely in grids hosting international oil companies. Furthermore, we find that international oil firms further state repression especially under insecure property rights.
\end{abstract}

\section{Introduction}

According to the think tank Revenue Watch Institute (2013: 3), the fate of the resource rich countries crucially hinges "on how they manage their oil, gas and minerals." This observation reflects the emerging consensus in policy circles that these states can avoid the ills of resource abundance, such as slowing development and an increased risk of political violence, through good governance. Yet, the empirical literature on the resource curse continues to provide mixed results. While Ross $(2012,2015)$ establishes that oil and gas wealth undermines democracy, slows (with some exceptions) economic growth, and increases the risk of civil war, other

Previous versions of this paper have been presented at the SVWP conference 2016 in Basel, the University of Essex, Humboldt University Berlin, the University of Konstanz, and Science Center Berlin (WZB). The authors would like to thank participants for their helpful comments and Korbinian Jellinek, Maik Maerten, Anna Noh, Leonhard Oswald, Juliane Giesen, Philipp Gottstein, David Ohlig, Thomas Wahl, Mario Krauser, Tobias Herrmann and Anne-Kathrin Stroppe for research assistance.

* Corresponding author.

** Corresponding author.

E-mail addresses: tim.wegenast@uni-konstanz.de (T. Wegenast), Gerald. schneider@uni-konstanz.de (G. Schneider). researchers have come up with less clear cut results (e.g. Alexeev \& Conrad, 2009; Brunnschweiler \& Bulte, 2008; Haber \& Menaldo, 2010).

Studies on the resource conflict nexus have so far neglected the question of how states regulate the access to their natural re sources. We maintain that the disruptive effects of natural re sources are not merely a function of, for instance, resource type, resource location, mode of extraction or the point in time at which revenues are recovered, as frequently discussed in the literature (see, for example Humphreys, 2005; Le Billon, 2008; Lujala, 2009, 2010; Lujala, Petter Gleditsch, \& Gilmore, 2005; Snyder \& Bhavnani, 2005). Rather, we seek to highlight one important and widely ignored condition under which resources may unleash violence: the question of whether resource extraction is publicly, privately, domestically or internationally controlled.

The resource conflict literature has, in our view, not provided conclusive findings because of its focus on large scale conflicts such as civil wars and its frequent reliance on aggregate data that typi cally use the country year as the unit of analysis. Addressing these shortcomings, this article advances a political economy framework of the resource conflict nexus and empirically tests the impact of different resource control rights regimes on state repression. The ownership of resource extracting companies may in this 
perspective affect the local conflict risk in different ways. On the one hand, multinational companies may adopt modern and environmentally friendly technologies and corporate social re sponsibility (CSR) practices more easily than local firms, thereby reducing the potential for local socio environmental grievances (Cole, Elliott, \& Strobl, 2008; Eskeland and Harrisson, 2003; Zarsky, 1999). At the same time, domestic state owned enterprises are more frequently involved in distributional conflicts over resource rents (Karl, 1997; Mommer, 1996). On the other hand, foreign controlled resource extraction often instigates resentment through the perception that the foreign owners act like neo imperialists (Kohl \& Farthing, 2012; Oneal \& Oneal, 1988). Espe cially the employment of foreign workers fuels this grievance. In addition, international companies tend to operate at their capacity limit due to expropriation fears, thereby being less likely to inter nalize their socio environmental costs.

Testing the impact of ownership rights on the resource curse has so far been nearly impossible in light of the huge variation of ar rangements within the same country. In this article we examine the influence of resource control rights regimes on social conflict by employing a disaggregated analysis. To this end, we develop a new theoretical argument that links commodity driven societal dissent and state repression to control rights regimes of diamond and gold mines as well as oil and gas fields in Sub Saharan Africa. The analysis of over 8400 grid cells in 38 African states for the period from 1997 to 2014 reveals that internationally controlled hydro carbon production increases the incidence of governmental violence against civilians. Furthermore, we show that this effect is particularly strong in an environment in which property rights are only insufficiently protected.

\section{Natural resource and intrastate violence: under what conditions?}

Studies on the link between natural resources and intrastate conflict have grown steadily in recent years. The empirical evi dence, however, is mixed. ${ }^{1}$ While several quantitative studies find a positive association between resource extraction and armed con flicts or civil wars (Collier and Hoeffler, 2004; Lei \& Michaels, 2014; Lujala, 2010; Ross, 2006, 2012), others question the conflict enhancing effect of resources (Brunnschweiler \& Bulte, 2009; Smith, 2004; Thies, 2010). Recent work stresses the need to examine the precise conditions under which primary commodities act as a catalyst for violence (for example, Basedau \& Richter, 2014). Contextual conditions identified in the literature include the char acteristics of the available resource (Le Billon, 2008; Lujala, 2010; Ross, 2003, 2012; Snyder \& Bhavnani, 2005), the ratio between resource abundance and dependence (Basedau \& Lay, 2009) or the socio political environment under which resources are extracted (Basedau \& Pierskalla, 2014; Sorens, 2011; Wegenast \& Basedau, 2014).

Furthermore, the resource curse literature has increasingly considered institutions as a mediating variable between resource wealth and social inequities. Rent seeking models found that po litical and social entrepreneurs try to monopolize the profits that natural commodities create. Inequality and social conflict, both in their violent and non violent manifestations, are the direct

\footnotetext{
${ }^{1}$ For comprehensive overviews of the causal mechanisms linking natural resources to economic, political and social development, see Ross (2015) or Van der Ploeg and Poelhekke (2017). For a summary of the different channels through which natural resources may influence countries' risk of experiencing internal conflict, see Collier and Hoeffler (2012). For a more general discussion of the natural resources and conflict linkage, see Koubi, Spilker, Bohmelt, and Bernauer (2014) and Cotet and Tsui (2013).
}

consequences of these resource grabbing activities (e.g. Torvik, 2001, 2002). Subsequent refinements of these models account for the incentives generated by political institutions (see, e.g. Mehlum, Moene, \& Torvik, 2006). Using country level measures of institu tional quality, Mehlum et al. (2006: 13) find "that the resource curse is weaker the higher the institutional quality." Robinson, Torvik, and Verdier (2006) similarly stress in an alternative model that institutions promoting accountability and state competence ameliorate the curse as they prevent politicians from over extracting the resources to pay off their supporters and to strengthen their hold on power.

These institutional explanations of the resource curse have intensified the debate centering on whether or not institutional quality and comparable indicators are truly mediating the impact of resource richness on development, intrastate stability, and other key outcomes. Recent studies have shown that institutions such as federalism, for example, may mediate the effect of natural re sources on intrastate conflict (Arellano Yanguas, 2011; Farzanegan, Lessmann, \& Markwardt, 2013). In a recent working paper, O'Reilly and Murphy (2015) show that strong economic and political in stitutions, including democratic regimes and free and open econ omies, mitigate the risk of territorial conflicts after major oil discoveries.

The present article builds on this literature that links resource extraction and institutions to the occurrence of violent and non violent intrastate conflict. Our approach explicitly departs from existing studies by introducing a micro level perspective that takes the diversity of ownership arrangements in resource abundant states into account. We believe that investors who are trying to maximize the profitability of investments in the resource sector have to reckon with both the national institutions as well as the way in which the extraction is managed locally. Although most of the previous studies have relied on country level evidence, we suggest that a more disaggregated research design is better suited to address the resource violence nexus.

So far, only a few studies have tested the impact of natural re sources on intrastate conflict through the lenses of a disaggregated analysis. Two recent papers rely on georeferenced data in analyzing the impact of mining on the risk of local conflict. Berman, Couttenier, Rohner, and Thoenig (2017) find that mining activity increases the probability and intensity of local violence, such as riots, protests or battles, in Africa. Using georeferenced data on oil and mineral discoveries in Africa, Arezki, Bhattacharyya, and Mamo. (2015) questions the link between natural resources and local conflict. They conclude that there is "no evidence of natural resources triggering conflict in Africa after controlling for grid specific fixed factors and time varying common shocks" (Arezki et al., 2015, p. 1). We maintain that the disregard of local owner ship arrangements accounts for the conflicting evidence that cur rent scholarship presents, showing that control rights regimes are crucial to better understand the link between commodities and local conflict.

Moreover, and in marked contrast to most of the previous studies, our examination does not assess the impact of natural re sources on major forms of violence such as armed conflict or civil wars. Rather, we focus on state repression as a proxy for societal dissent and local grievances. In contrast to geographically dispersed armed conflicts that are not bound to a particular resource producing region, repression is a more local phenomenon that can be causally linked to specific regional characteristics.

Few studies address the impact of natural resources on minor forms of conflict. On the country level, de Soysa and Binningsbø (2009) show that mineral and oil wealth increases repression. This finding is corroborated by DeMeritt and Young (2013) who find a positive relationship between a state relying on oil and the 
violation of personal integrity rights. In contrast, an analysis by Smith (2015) suggests that oil producing countries use less repression than others. All of these studies employ aggregated cross national data.

\section{Linking natural resource ownership to social conflict}

Countries vary with respect to the control rights regimes of their main natural resources (Luong \& Weinthal, 2010). While the state does not participate much in the oil and gas sector of South Sudan or the Democratic Republic of Congo (DRC), government actors control hydrocarbon production in Angola almost completely. Kenya's and Gabon's oil and gas lies mostly in the hands of inter national corporations, while Nigeria has established mixed own erships. Control rights regimes within the diamonds and gold industry also vary considerably both within and across countries. In Angola and Botswana, for example, the state holds significant shares of the majority of mines. A mix between privately and state owned mines characterizes the deposits in Ghana. Private owner ship arrangements, by contrast, dominate the diamond industry in South Africa, Lesotho or Guinea.

The peace and conflict literature has hardly addressed the variation in natural resource ownership patterns thus far. One exception to this trend is van der Ploeg and Rohner (2012: 1726), who develop a theoretical model showing how private and nationalized resource ownership influences the fighting effort in civil wars. In addition, Wegenast (2016) empirically demonstrates on an aggregated level of analysis that resource ownership matters for the prediction of the onsets of armed conflict. Haslam and Tanimoune (2016) find some empirical evidence for a link be tween ownership arrangements and local conflict. The authors use binary variables to measure the ownership of gold, silver and copper mining properties in Latin America. Relying on a self constructed dichotomous variable as an indicator of mining con flicts, the authors find a positive association between foreign ma jority ownership and the risk of local mining conflict. This finding, however, is not robust across all model specifications and is limited to five Latin American countries.

Introducing a more nuanced measure of the property rights structure of minerals and hydrocarbons in Sub Saharan Africa and relying on different indicators of local conflict, we seek to shed light on the role of resource extraction arrangements in explaining intrastate violence. We maintain that resource ownership struc tures may have both a direct and a more indirect effect on the local conflict risk. On the country level, the presence of state controlled resource extraction may further the greed of political actors and intensify competition for access to the key bodies responsible for managing resource revenue distribution, thereby furthering the risk of internal violence (cf. Wegenast, 2013, pp. 396-397). Furthermore, publicly controlled resource production may foster the risk of internal violence in the case of a negative price shock that robs the executive of the possibility to use the resource rents as a means to quell potential protests (Ross, 2012). On a more dis aggregated level, the type of extraction arrangement may also directly affect conflict incidence by generating grievances in the producing regions.

In a recent policy report, Davis and Franks (2014) analyze the main issues leading to company community conflict within the extractive sector. The authors find that environmental issues, such as pollution or competition over environmental resources, often trigger protests. The most common underlying factor, according to the study, are socio economic issues, in particular the distribution of the resource rents or undesired changes the extraction project has brought to the local culture and customs. We maintain in this article that the ownership structure of mining or hydrocarbon companies deeply affects the relationship between the resource extractors and the communities living around the mine or oil and gas fields. Mass media and NGOs report that the way in which privately owned and worldwide operating companies handle socio economic and environmental issues frequently provokes local resentment. Anglo Australian mining giant Rio Tinto or American mining company Freeport McMoRan are frequently tar geted by protests and riots around the world (London Mining Network, 2010; The Atlantic, 2011). Resentments and neo colonial rhetoric raised by the local population against Chinese mining and oil companies are present in many African states such as Zambia, Kenya, Cameroon, Mozambique, Niger, Zimbabwe, Angola, Tanzania and Nigeria (Spiegel Online International, 2010).

Media reports and some academic studies suggest that Chinese firms violate labor and environmental standards more frequently than other mining companies (Brautigam, 2009, p. 300; Kotschwar, Moran, \& Muir, 2011). Armony and Velazquéz (2015: 319) note that China's increasing presence in Latin America has created "anxieties due mainly to the perceived threats posed by environmental im pacts, outward migration, and the demand for natural resources."

Foreign or privately owned resource extracting firms may in light of this evidence create more discontent among the local population compared to domestic state owned companies. Foreign or private companies' main objective is profit maximization and they may be less inclined to internalize environmental costs than public firms in the absence of effective state regulation (Baumol \& Oates, 1988, pp. 15-18; Reinhardt, 1999, p. 10). Moreover, foreign resource extractors are often uncertain over whether governments of host countries will comply with the negotiated terms such as the length of their exploration licenses. They operate under the con stant fear that the state might expropriate them (see e.g. Guriev, Kolotilin, \& Sonin, 2011, pp. 303-304; Kennedy \& Tiede, 2011). The lingering doubts over states' adherence to contractual obliga tions and compliance with property rights in many African, Asian or Latin American countries lead private firms to extract as much re sources as possible in the shortest amount of time (cf. Ludwig, 2012). In contrast, domestic state owned companies face longer time horizons and may have higher incentives to develop better relationships with local communities.

Long (1975) was among the first to show that firms with a more limited time horizon will produce on a higher rate. In fact, recent work by Costello and Grainger (2015) confirm that when resource extracting firms face weak property rights, they tend to pressure the regulator to allow resource production at an inefficiently higher rate. Using panel data on global fisheries, the authors find that "regulators are significantly more conservative in managing re sources for which strong individual property rights have been assigned to firms" (Costello \& Grainger, 2015, p. 1). In a similar vein, a formal model by Che and Qian (1998) suggests that - under insecure property rights - local government ownership increases local public goods provision.

Facing limited time horizons, private mining or oil companies frequently lack the incentives to comply with environmental or labor standards, may be less sensitive towards the needs and in terests of the local community and may be less inclined to maintain a credible and ongoing dialogue with stakeholders. Descriptive evidence corroborates this tendency. A series of African countries such as Niger, Chad or Gabon, for example, have seized major oil tracts from Chinese companies due to gross environmental negli gence (The New York Times, 2013). Shell has prompted local environmental protests in Nigeria for many decades (The Guardian, 2011). Examples of environmental opposition against the opera tions of international mining companies are plentiful. Since Toronto based Barrick Gold Corp, the largest gold producer in the world, has acquired the Chilean Pascua Lama gold, silver and 
copper open pit mine in 1994, environmental concerns among the local communities, especially the fear of water shortage and pollution, has grown steadily and led to widespread protests (see Gordon \& Webber, 2008, pp. 75-76). The activities of mining giant Rio Tinto have provoked protests following violations of environ mental laws in various locations, including the QMM Mine in Madagascar or the Rossing Uranium Mine in Namibia (London Mining Network, 2010).

Besides facing disincentives to implement stricter environ mental standards or invest in local communities, international mining firms may also be less concerned with employing a local labor force than state owned, local companies. China, for example, is well known for hiring its own natives in resource extraction projects within several African countries such as Zambia, Kenya and Nigeria, generating discontent among the local population. In fact, the employment of Chinese labor rather than local workers in Chinese sponsored projects in Ethiopia, Sudan and Namibia has been criticized locally (Alden, 2005) and, according to Adisu, Sharkey, and Okoroafo (2010), African labor has not benefited from Chinese investment. In South Africa, private gold mining companies employ a high share of foreign and sub contracted la bor. Amongst the larger firms, "foreign labour makes up 77.8\% of the workforce" (Crush, Ulicki, Tseane, \& van Veuren, 2001, p. 13). Domestic state owned firms, in contrast, may have higher in centives to employ local labor in order to increase the government's legitimacy.

As noted by Giuliani and Macchi (2013: 1), governments of developing countries compete for attracting multinational corpo rations, thereby often prioritizing economic goals over funda mental human rights. Studying the activity of multinational oil and mining companies in Nigeria, South Africa and Zambia, Eweje (2009) finds that multinationals have been widely criticized by local governments and trade unions for employing expatriates at the expense of local labor. The author shows that the number of expatriate workers decreased significantly in the Zambian Cop perbelt region after the nationalization of mines in 1969 (Eweje, 2009 , p. 213). The privatization of Zambian copper mines to foreign investors between 1997 and 2001 resulted in local job losses (Mususa, 2010), an increase in expatriate workers and casualization of the labor force, mostly through the employment of subcontracting (Burawoy, 2014, p. 972). Focusing on Zambian copper mines and Tanzania's textile industry, Lee (2009) demon strates that the presence of Chinese investments has led to the pursuit of flexible labor regimes with increased precarious employment. According to the author, the implementation of ca sual and contract jobs was accompanied by widespread strikes in both countries. The use of imported and subcontracted labor by Chinese investors in Africa has been described by various authors (Cooke, 2014; Mohan, 2013).

Local resentments over the employment of foreign labor by international oil or mining companies can be observed on a worldwide scale. Patey (2012: 517) describes how discontent over the lack of employment opportunities for local workers led to protests in Sudan. In Kenya's Turkana County, the oil firm Tullow had to temporary shut down its operations following protest against the influx of foreign workers in 2013 (Financial Times, 2013). For the same reason, oil employees promoted large pro tests during 2010 and 2011 in Gabon (BBC, 2010) and during 2002 in Nigeria (The New York Times, 2002). Following severe protests and riots among coal and copper miners in Zambia, President Michael Sata asked the Chinese government to improve workers' conditions and observe limits on how many foreign workers Chi nese companies bring into the country (BBC, 2011).

In addition to the arguments developed above, the presence of international companies and foreign workers often produce feelings of exploitation among local actors. Zaheer (1995: 343) suggests that foreign firms frequently lack legitimacy. The perception that multinational companies make a profit on the backs of cheap labor is widespread in the developing world and fuels conflict between firms and communities (Blowfield, 2005; Child, 2002). It is against this backdrop not surprising that trans national extractive corporations are frequently viewed as a new form of imperialism and that their activities have given rise to neocolonialist rhetoric (Kohl \& Farthing, 2012; Oneal \& Oneal, 1988; Shaker, 1970). According to Obi (2010: 220), resistance “represents a mass project of restitution and self determination arising from the exploitation of the region's oil by multinational oil corporations (MNOCs) backed by the Nigerian state" in Nigeria. Resource extraction by multinational companies is often consid ered a sellout of the country by local communities and opposition leaders (Manzano \& Monaldi, 2010, p. 426; The Guardian, 2007). This neo colonialist view serves as a source of mobilization against foreign entrepreneurs, making international resource extracting companies more vulnerable to protest than local firms.

The presence of foreign oil companies in the Niger Delta has generated resentment and feelings of exploitation among locals, leading to the kidnapping of foreign workers and other forms of violence. China's control of natural resource production in several African countries has generated widespread anti Chinese senti ment in many regions (The Economist, 2011; The New Yorker, 2013). Sierra Leone's Koidu diamond mine experienced violent protest against a South African based company following claims of racism and bad working conditions in 2012 (BBC, 2012). Illegal mining perpetuated by foreign workers at diamond and gold mines such as in Ghana's Ashanti region strengthens the neo colonialist resentment among the local population (The Atlantic, 2013).

The employment of foreign labor, socio environmental griev ances caused by private firms facing limited time horizons or perceived neocolonial impositions may foster social conflict within regions hosting international mining or oil companies. However, as suggested by some authors, international operating firms may be more likely to adopt cleaner technologies (Cole et al., 2008; Eskeland and Harrisson, 2003; Zarsky, 1999). Zarsky (1999), for example, argues that OECD based multinationals tend to more often employ cleaner technology and possess more sophisticated environmental management systems than many domestic firms in developing countries. Therefore, international corporations may actually reduce the incidence of environmental grievances. More over, due to pressure from international NGOs and their size, multinational oil or mining corporations may be more likely to implement CSR practices than local firms. To overcome the liability of foreignness (see Eden \& Miller, 2004), ensure smooth operations and avoid protests often driven by neo imperialist resentments, foreign companies might spend more on the development of local communities. In addition, natural resources owned by the state often instigate distributional conflicts over rents among social ac tors such as elites, unions, the military or geographical regions (Warenfels, 2002). This article provides a first extensive empirical test of which type of resource ownership structure is in fact more likely to affect the risk of social conflict.

\section{Research design}

\subsection{Dependent variable}

Resource related conflict often involves government repression. Different authors have shown how resource related communal grievances have escalated from local protests to violent intrastate conflict with the employment of major state force in countries such as Nigeria (Obi, 2010) and Sudan (Patey, 2012). Qualitative studies 
provide in depth descriptions of how protest over the activities of multination oil companies by different ethnic groups prompted a violent response by the state in the Niger Delta (Mandy, 1999; Ukeje, 2001).

Media reports on violent government repression of community protest are plentiful. For example, around the Tanzanian North Mara gold mine owned by an African subsidiary of mining giant Barrick Gold, police have killed dozens of villagers over the past years as a consequence of locals searching for precious metals in the waste dumps and pits of the mine (The Guardian, 2014). The mine has a history of pollution allegations, human rights abuses and local protests (The Guardian, 2015). In the last years, citizens protesting for jobs in oilfields have been violently suppressed in Tanzania (The East African, 2013) and Niger (Porter, 2013). International oil and mining companies have been accused of complicity in human rights abuses and repression in different African countries. Ac cording to some NGOs, the British oil company BP has encouraged repression of protesters in Algeria (c.f. Platform, 2014). In Nigeria, Sudan or Tanzania, multinational oil companies face lawsuits for allegedly helping governments to suppress dissent and violate human rights (c.f. Business and Human Rights Resource Center, 2013). Media reports describe how Shell supposedly cooperated with the Nigerian military to violently repress protests against environmental degradation, leading to major killings in the Niger Delta during the 1990s (The Guardian, 2011).

Repression becomes a feasible response to dissent especially within states with a low capacity in handling threat compared to the actual level of dissent (Poe, 2004). These countries lack the proper means to address socio political problems and often resort to repression. As outlined above, resource based incidences of protest and demonstrations often lead to state violence against civilians in Africa. By employing government repression as a proxy for societal dissent, we avoid potential problem of protest event data such as underreporting and inconsistency (see Cook, Blas, Carroll, \& Sinha, 2017).

Assuming that repression reflects the level of dissent within African countries, we test the effect of different resource control rights regimes on one sided violence employing a measure indi cating whether governmental authorities or pro government groups used non lethal or lethal repression against individuals, an alleged opposition group or an opposition movement. The dummy variable "government repression" equals " 1 " if a grid experienced at least one incidence of government repression in a given year and is taken from the Social Conflict in Analysis Database (SCAD) version 3.1 (see Salehyan, HendrixHamnerCase, Linebarger, Stull, \& Williams, 2012). We decided to incorporate both lethal and non lethal repression into our dependent variable mainly out of methodological reasoning. As the two types of state repression are rare events, we sought to maximize the potential matching be tween repression and resources control rights within our sample, thereby ensuring a higher validity of the results. Theoretically, we cannot find reasons for why the intensity of state repression should be correlated with natural resources' ownership structure.

\subsection{Independent variables of interest}

In order to test whether natural resources control rights regimes can explain the incidence of social conflict at the sub national level, we consider deposits of gold, diamonds, oil and gas using a new dataset. We collected data on 38 sub Saharan African states, of which 11 possess major diamond mines, 15 major gold mines and 17 major onshore oil or gas fields. Covering the period between 1997 and 2014, we employ georeferenced data at the grid cell level using grid years as the unit of analysis.

The data on diamond and gold deposits primarily rely on three main sources. First, we gathered specific information on each dia mond and gold deposit and its ownership structure using the mining resource Infomine (Infomine, 2013). The company's data base contains information on the location, production volume and status as well as control rights of worldwide mines. In addition, it provides a compilation of mining firm reports on their ownership structure, major mining deals and changes in extracting rights. The review of these reports enabled us to code firms' ownership structure and mining licenses of the majority of gold and diamond mines in sub Saharan Africa for the period 1997-2014. In a second step, we relied on data from the U.S. Geological Survey (USGS), a US based scientific organization that publishes yearly minerals reports for all countries, ${ }^{2}$ and on specifications provided in the respective mining firms' websites in order to compensate for incomplete or missing information. Following this procedure, we were able to identify a total of 174 diamond mines and 351 gold mines and their respective contractors for the given period.

For the identification of oil and gas fields and their respective operators we first drew on a list of oil and gas fields that were either active or under exploration between 1997 and 2015 with the cor responding main operating companies provided by the commercial data service "GlobalData." ${ }^{3}$ Departing from this list, we relied on USGS, on the web based global information services "Rigzone" 4 and "energy pedia news" ${ }^{5}$ as well as on the websites of each oil and gas company to assess the ownership structure of the respec tive operator, code the ownership history of all fields back to 1997 and identify their production status for the analyzed period. Through this procedure, we coded a total of 632 onshore oil and gas fields and the ownership structure of the respective operators. ${ }^{6}$

With the help of latitude and longitude coordinates collected during our coding work, we were able to assign each mine or hy drocarbon field to a specific grid. Our GIS based dataset therefore provides information on the average share of diamonds, gold or hydrocarbons extracted by either domestic private, state owned private, foreign private or foreign state owned companies within each grid. For the purpose of our analysis, we generate two main independent variables of interest: First, we create an international ownership variable, which distinguishes between international diamond and gold mines and international oil and gas fields. These variables measure the average total share of mines or oil and gas fields owned by international companies within a grid, ranging from 0 to $100 \%$. Second, we code a public ownership measure, covering the total average share of mines or oil and gas fields within a grid owned by the state of the host country. In addition, we create a variable counting the number of mines and hydrocarbon fields per grid, based on our own data.

Our data on the control rights regimes of the surveyed natural resources shows that the 38 African states under consideration differ considerably in their ownership patterns. In the diamonds industry, private ownership dominates in the majority of countries. However, a high level of variance exists both within and across states. While diamond mines in South Africa, Guinea and Sierra Leone are almost entirely owned by the private sector, the states of Angola, Botswana, Ghana and Namibia hold considerable shares of many diamond mines countrywide. In most of the sampled coun tries, state ownership co exists with private investment. Extraction

\footnotetext{
${ }^{2}$ These reports are available online under http://minerals.usgs.gov/minerals/ pubs/country/.

${ }^{3}$ See https://www.globaldata.com.

4 See http://www.rigzone.com.

5 See http://www.energy-pedia.com.

${ }^{6}$ Given that conflict is rarely located at offshore oil or gas facilities, we concentrate on onshore fields.
} 
property rights also vary in the gold mining industry for the African countries under consideration. While gold extraction is done pri marily by international firms in the majority of countries (e.g. Botswana, DRC, Ghana, Guinea, Mali, Senegal, South Africa, Tanzania, Zambia), other countries are characterized by high rates of state participation (e.g. Ivory Coast, Sudan, Eritrea, Zimbabwe). In the oil and gas industry, the state has large participation shares in countries such as Nigeria, Angola, Kenya and Senegal. Hydrocarbon production controlled by international companies dominates in countries like Mozambique, DRC, Chad and Sudan. In most of the countries, private and state hydrocarbon production coexists.

\subsection{Control variables}

We include several structural variables in our data, which are based on the information provided by the PRIO GRID 2.0 dataset (Tollefsen, Strand, \& Buhaug, 2012). This data collection allows for disaggregated analysis at the grid cell level, as it is not bound to politico geographical structures such as state borders. PRIO GRID globally covers all terrestrial entities at a resolution of $0.5 \times 0.5$ decimal degrees, corresponding to about $55 \times 55 \mathrm{~km}$ at the equator. The following variables used in our analyses are taken from different data files of the PRIO GRID project.

We measure economic development using the Geographically based Economic Data (G Econ) by Nordhaus (2006). These data contain the gross cell product measured in US dollars of each terrestrial grid cell to account for their economic activity. ${ }^{7}$ Other control variables are an index measuring the grid's share of mountainous terrain within the cell based on elevation, slope and local elevation range ${ }^{8}$ and grids' population density. ${ }^{9}$ Furthermore, we include the number of discriminated groups within each cell as measured by the geo referenced Ethnic Power Relations Dataset (GeoEPR ETH) (see Wucherpfennig, Weidmann, Girardin, Cederman, \& Wimmer, 2011) as well as the Polity II score for po litical regimes from the Polity project (see Gurr, Jaggers, \& Moore, 1989 ) in order to account for the level of democracy. ${ }^{10}$

\section{Estimation technique and results}

We expect that natural resources control rights regimes matter for explaining differences in the incidence of social conflict in resource rich regions. Fig. 1 locates diamond and gold mines as well as oil fields within some western sub Saharan African countries. We classified a mine or oil field as predominantly internationally owned whenever more than $50 \%$ of the mine is controlled by in ternational companies. Mines or oil fields denoted as public have a state participation of more than $50 \%$. The figure also shows the incidence of state repression against civilians as measured by the SCAD dataset for the period 1997-2014.

Overlaps between internationally controlled mines or oil fields and government repression can be observed in countries such as DRC, Gabon, Ghana, Niger or Sudan. In our sample, there are 167 grids showing internationally controlled gold or diamond pro duction, while a total of 79 grids exhibit state controlled gold or diamond production. For oil and gas fields, 87 grids exhibit internationally controlled production while 50 grids show state

\footnotetext{
7 Since this variable is only available for 1990, 1995, 2000 and 2005, we interpolate the intervals with the value corresponding to the start year of each interval. 8 Corresponds to the variable named "mountain_mean" in the PRIO-GRID dataset.

9 Population density is the quotient between the variables "pop_gpw_sum" and "landarea" from the PRIO-GRID dataset. For table formatting purposes, we transformed this variable by dividing it by 100 .

${ }^{10}$ This is the only variable measured at the country level.
}

controlled production. Merely five grids hosting state owned gold or diamond mining companies experienced a total of seven events of government repression. In contrast, 16 grids with internationally controlled gold or diamond production experi enced a total of 34 incidences of state repression.

To estimate whether there is a systematic effect of resource control rights on state repression, we employ two level mixed ef fects logit models with random intercepts representing unobserv able heterogeneity at the country level. Multilevel analysis is a statistical technique that allows for the analysis of independent variables operating at different levels, i.e. where the units of anal ysis are hierarchically nested within groups (Hox, 2010). Thereby, the core idea of multilevel regression modeling is to account for a hierarchically structured data by implementing random effects at the various hierarchical levels. Thereby, we are able to correct the estimations for the dependence of residuals that arise between grids within countries. In conceptual terms, it means that each country is allowed to have its own mean level of social conflict. This strategy also allows us to exploit the panel structure of our dataset and thus variation for the same grid over time.

Table 1 below reports the yearly risk of a grid experiencing state repression. ${ }^{11}$ To account for possible spatial correlation of govern mental violence, we include a spatial violence lag indicator that gives the share of ongoing state repression among contiguous cells in the same country in the given year. ${ }^{12}$ Models 1 and 2 report the general effect of oil and gas fields as well as gold and diamond mines on state repression. As shown in the fully specified Model 2, the more hydrocarbon fields in one grid, the higher the risk of one sided state violence against civilians. This result is in line with the findings of de Soysa and Binningsbø (2009) and DeMeritt and Young (2013) reviewed above. In contrast, the number of gold and diamond fields does not seem to influence the risk of repression.

In a second step, we assess the impact of mines' control rights structure on government repression. The variables state mine and international mine denote the percentages of gold and diamonds mines controlled by either domestic, state owned or international companies within one grid. The analysis suggests that interna tionally controlled diamond and gold mines - in contrast to pub licly owned mines - positively affects the risk of repression when all grid cells are considered as unit of analysis (Model 4). However, a direct comparison between internationally vs. state controlled mineral production (i.e., when only diamond and gold producing grids are considered) reveals no systematic effect of mines' ownership structure on state violence (Model 6).

Table 2 summarizes the effect of ownership structures of oil and gas fields on state repression. As becomes evident from Models 2 and 4 , the higher the percentage of internationally controlled hy drocarbon mines within one grid, the more likely it will experience incidences of state repression. State controlled hydrocarbon pro duction, in contrast, is not associated with an increased violence risk. This result holds both for an all grid sample (Model 2) as well as for a direct comparison between internationally versus state controlled hydrocarbon fields (Model 4). The coefficients of the

\footnotetext{
11 The multilevel models were run using the "xtmelogit" command in Stata 14 with seven integration points. Increasing the integration points did not change the results in a substantial way.

${ }^{12}$ For table formatting purposes, we transformed this variable by multiplying it by 100 (for results in Table 1 and models 1 and 2 of Table 2) or by 1000000 (all other models). As some authors show that including a lagged dependent variable in a mixed model may lead to severe bias (c.f. Allison, 1990; 2005), we decided not to include a one year lag of state repression into our model. We recalculated all subsequently shown models employing a lagged dependent variable and our main results did not change in a substantial manner.
} 


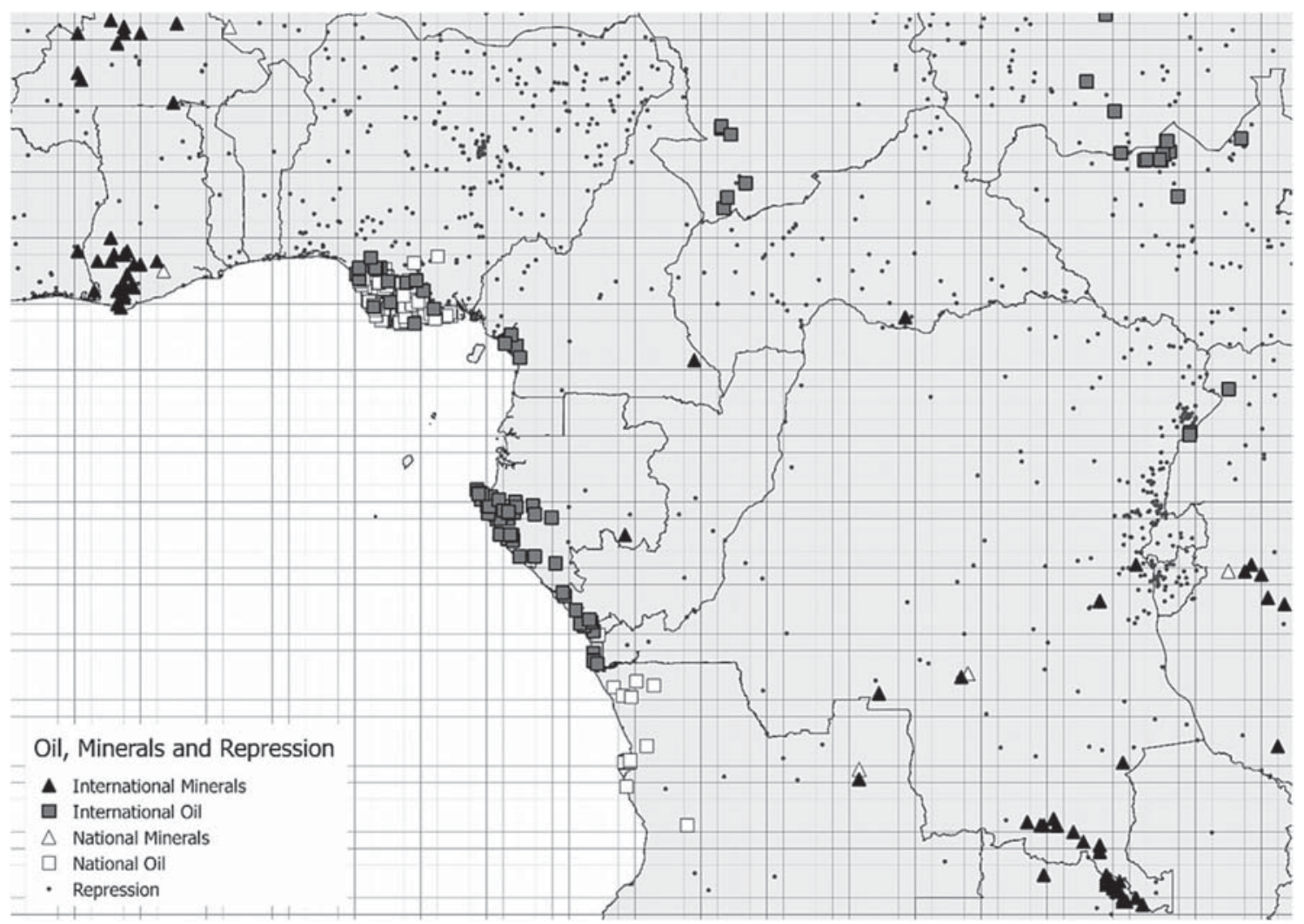

Fig. 1. Control rights of mines, oil fields and government repression in sub-Saharan Africa.

Table 1

Effect of mineral and hydrocarbon production on government repression at grid level, 19972014 .

\begin{tabular}{|c|c|c|c|c|c|c|}
\hline & (1) & (2) & (3) & (4) & (5) & (6) \\
\hline & All Grids & All Grids & All Grids & All Grids & Mining Grids & Mining Grids \\
\hline $\begin{array}{l}\text { Grid-Level Variables } \\
\text { oil \& gas fields } \\
\text { diamond \& gold mines }\end{array}$ & $\begin{array}{l}0.061^{* * *} \\
(0.006) \\
0.177^{* * *} \\
(0.023)\end{array}$ & $\begin{array}{l}0.044^{* * *} \\
(0.006) \\
0.039 \\
(0.034)\end{array}$ & & & & \\
\hline state mine & & & $\begin{array}{l}1.201 \\
(0.615)\end{array}$ & $\begin{array}{l}1.060 \\
(0.680)\end{array}$ & $\begin{array}{l}0.395 \\
(0.647)\end{array}$ & $\begin{array}{l}0.545 \\
(0.751)\end{array}$ \\
\hline international mine & & & $\begin{array}{l}1.044^{* * *} \\
(0.225)\end{array}$ & $\begin{array}{l}0.860^{* *} \\
(0.253)\end{array}$ & $\begin{array}{l}0.639 * \\
(0.308)\end{array}$ & $\begin{array}{l}0.342 \\
(0.376)\end{array}$ \\
\hline population density & & $\begin{array}{l}0.233^{* * *} \\
(0.012)\end{array}$ & & $\begin{array}{l}0.232^{* * * *} \\
(0.012)\end{array}$ & & $\begin{array}{l}0.571^{* * * *} \\
(0.088)\end{array}$ \\
\hline rough terrain & & $\begin{array}{l}0.103 \\
(0.145)\end{array}$ & & $\begin{array}{l}0.089 \\
(0.145)\end{array}$ & & $\begin{array}{l}1.286^{*} \\
(0.505)\end{array}$ \\
\hline excluded groups & & $\begin{array}{l}0.203^{* *} \\
(0.066)\end{array}$ & & $\begin{array}{l}0.268^{* * * *} \\
(0.065)\end{array}$ & & $\begin{array}{l}-0.610 \\
(0.439)\end{array}$ \\
\hline per capita GDP & & $\begin{array}{l}0.200^{* *} \\
(0.072)\end{array}$ & & $\begin{array}{l}0.269 * * * \\
(0.060)\end{array}$ & & $\begin{array}{l}-0.572^{*} \\
(0.228)\end{array}$ \\
\hline $\begin{array}{l}\text { spatial lag } \\
\text { polity2 }\end{array}$ & $\begin{array}{l}0.085^{* * *} \\
(0.008)\end{array}$ & $\begin{array}{l}0.604^{* * *} \\
(0.101) \\
-0.002 \\
(0.013)\end{array}$ & $\begin{array}{l}0.086^{* * *} \\
(0.008)\end{array}$ & $\begin{array}{l}0.585^{* * *} \\
(0.101) \\
-0.002 \\
(0.013)\end{array}$ & $\begin{array}{l}0.130^{* * *} \\
(0.030)\end{array}$ & $\begin{array}{l}0.459 \\
(0.526) \\
-0.095 \\
(0.054)\end{array}$ \\
\hline Variance (Intercept) & $\begin{array}{l}1.131^{* * *} \\
(0.136)\end{array}$ & $\begin{array}{l}0.967^{* * *} \\
(0.127)\end{array}$ & $\begin{array}{l}1.132^{* * *} \\
(0.136)\end{array}$ & $\begin{array}{l}0.973^{* * *} \\
(0.127)\end{array}$ & $\begin{array}{l}1.386^{* * *} \\
(0.464)\end{array}$ & $\begin{array}{l}1.076 \\
(0.514)\end{array}$ \\
\hline LR test $\mathrm{p}$ value & 0.0000 & 0.0000 & 0.0000 & 0.0000 & 0.0000 & 0.0000 \\
\hline Observations & 151,220 & 111,968 & 151,083 & 111,846 & 3650 & 3063 \\
\hline Number of groups & 47 & 39 & 47 & 39 & 28 & 24 \\
\hline
\end{tabular}

NOTE: Two-level mixed-effects logit models with random intercept. State repression as dependent variable.

Standard errors in parenthesis ${ }^{*} \mathrm{p}<0.05,{ }^{* *} \mathrm{p}<0.01,{ }^{* * *} \mathrm{p}<0.001$. 
Table 2

Effect of hydrocarbon control rights on government repression at grid level, 19972014.

\begin{tabular}{|c|c|c|c|c|}
\hline & (1) & $(2)$ & (3) & (4) \\
\hline & All Grids & All Grids & Oil\&Gas-Producing Fields & Oil\&Gas-Producing Fields \\
\hline $\begin{array}{l}\text { Grid-Level Variables } \\
\text { state fields }\end{array}$ & $\begin{array}{l}3.207^{* * *} \\
(0.439)\end{array}$ & $\begin{array}{l}0.281 \\
(0.500)\end{array}$ & $\begin{array}{l}2.315^{*} \\
(0.908)\end{array}$ & $\begin{array}{l}1.079 \\
(1.087)\end{array}$ \\
\hline international fields & $\begin{array}{l}0.923^{* *} \\
(0.357)\end{array}$ & $\begin{array}{l}1.373^{* * *} \\
(0.342)\end{array}$ & $\begin{array}{l}2.715^{* *} \\
(0.819)\end{array}$ & $\begin{array}{l}3.222^{* * *} \\
(0.914)\end{array}$ \\
\hline population density & & $\begin{array}{l}0.251^{* * *} \\
(0.014)\end{array}$ & & $\begin{array}{l}0.242^{* * * *} \\
(0.062)\end{array}$ \\
\hline rough terrain & & $\begin{array}{l}0.131 \\
(0.146)\end{array}$ & & $\begin{array}{l}-8.462 \\
(6.258)\end{array}$ \\
\hline excluded groups & & $\begin{array}{l}0.229^{* *} \\
(0.066)\end{array}$ & & $\begin{array}{l}0.465 \\
(0.285)\end{array}$ \\
\hline per capita GDP & & $\begin{array}{l}0.231^{* * * *} \\
(0.062)\end{array}$ & & $\begin{array}{l}0.077 \\
(0.283)\end{array}$ \\
\hline spatial lag & $\begin{array}{l}0.0892^{* * *} \\
(0.008)\end{array}$ & $\begin{array}{l}0.596^{* * *} \\
(0.101)\end{array}$ & $\begin{array}{l}0.407 \\
(1.030)\end{array}$ & $\begin{array}{l}0.336 \\
(1.076)\end{array}$ \\
\hline polity2 & & $\begin{array}{l}-0.005 \\
(0.013)\end{array}$ & & $\begin{array}{l}0.081 \\
(0.069)\end{array}$ \\
\hline Variance (Intercept) & $\begin{array}{l}1.130^{* * * *} \\
(0.136)\end{array}$ & $\begin{array}{l}0.968^{* * *} \\
(0.127)\end{array}$ & $\begin{array}{l}1.869 * * * \\
(0.695)\end{array}$ & $\begin{array}{l}1.866^{* * *} \\
(0.626)\end{array}$ \\
\hline LR test $\mathrm{p}$ value & 0.0000 & 0.0000 & 0.0001 & 0.0000 \\
\hline Observations & 150,826 & 111,654 & 1346 & 1150 \\
\hline Number of groups & 47 & 39 & 19 & 17 \\
\hline
\end{tabular}

NOTE: Two-level mixed-effects logit models with random intercept. State repression as dependent variable.

Standard errors in parenthesis ${ }^{*} \mathrm{p}<0.05,{ }^{* *} \mathrm{p}<0.01,{ }^{* * *} \mathrm{p}<0.001$.

control variables are largely in line with expectations: grids with a high population density and excluded ethnic groups are more likely to experience government repression. In addition, economically more prosperous areas are more affected by state violence (see Model 2). The level of democracy as measured by the Polity2 Index is negative but not significant. In fact, some authors find that repression is lower only at very high levels of democracy on the polity scale (de Soysa \& Nordås, 2007). The fact that most of the African countries do not reach high values on the polity scale might explain the lack of significance for this variable.

Several robustness checks were conducted to assess the sensi tivity of our results. Since Nigeria shows the highest number of state repression events, hydrocarbon related conflicts as well as oil and gas fields in the sample and hydrocarbon fields are mostly controlled by a mix of foreign companies and the state, we excluded this country from the regressions reported in Table 2. Qualitatively similar results were achieved by this procedure. We also tested whether the effect of internationally or state controlled resource production differs by country using both random intercepts and slopes. Likelihood ratio tests showed that there is no country to country variation for the effect of resource ownership on govern ment repression. We addressed potential problems arising from omitted variable bias by including a set of control variables that may jointly explain resource ownership structures and state repression. Table A1 in the Appendix shows that our results are robust to the inclusion of variables measuring level of corruption (Model 1), fiscal capacity (Model 2), level of political competition (Model 3) and quality of government (Model 4). ${ }^{13}$ Finally, our main

\footnotetext{
13 To measure level of corruption, we employed the variable "freedom from corruption" from the Heritage Foundation. Fiscal capacity denotes the level of state tax revenue as a percentage of GDP taken from the World Development Indicators. The level of competition is measured by the extent of government restriction on political competition (variable PARCOMP from the Poliy4 Project, see Gurr et al., 1989). The indicator for quality of government comes from the International Country Risk Guide. All of these variables were taken from the Quality of Government Project database (see Teorell et al., 2013).
}

findings remain qualitatively unchanged when only instances of lethal state repression are used as dependent variable.

In the theoretical part of this article, we maintain that interna tional oil or mining companies generate societal dissent and state repression especially when facing limited time horizons. Under an environment of weak property rights enforcement and political uncertainty, firms may fear expropriation and are thereby less likely to internationalize socio environmental costs. In order to test this claim, we explore interaction effects between hydrocarbon ownership structures and property rights enforcement as well as inconsistent political regimes (i.e., regimes that are neither fully democratic nor fully autocratic) on state repression.

Table 3 above corroborates our hypothesis. Model 1 shows the joint effect of lack of property rights enforcement and hydrocarbon ownership structures. ${ }^{14}$ It reveals that under insecure property rights, international oil and gas fields controlled by international companies increase the risk for state repression. A similar effect cannot be found for state controlled hydrocarbon extraction. In contrast, international hydrocarbon companies generate less gov ernment repression compared to local, state owned firms within stable democratic regimes (i.e., under high values on the Polity2 scale, see Model 3). Graphs 1 and 2 below plot the marginal effects of internationally controlled hydrocarbon production on the risk of repression under weak or moderate to strong property rights enforcement (i.e., when the property rights score from the Heritage Foundation is below or above 40, respectively). As can be noted, the risk of repression rises substantially with increasing shares of oil or gar extracted by international companies under an environment of

\footnotetext{
${ }^{14}$ As an indicator for property rights enforcement, we employed the degree to which a country's laws protect private property rights and the degree to which its government enforces those laws from the Heritage Foundation. We rescaled the original variable in a way that high values indicate weak property rights enforcement. To facilitate interpretation of the interaction terms, we use predominantly internationally-controlled hydrocarbon fields (i.e., at least $51 \%$ of the field is controlled by international firms) or predominantly state-controlled fields as measures of the resource ownership structure.
} 
Table 3

Effect of hydrocarbon control rights on government repression under economic and political uncertainty, 19972014

\begin{tabular}{|c|c|c|c|}
\hline & (1) & (2) & (3) \\
\hline & Oil producing grids & Oil producing grids & Oil producing grids \\
\hline $\begin{array}{l}\text { Grid-Level Variables } \\
\text { state fields }\end{array}$ & $\begin{array}{l}0.058 \\
(2.560)\end{array}$ & $\begin{array}{l}1.102 \\
(0.891)\end{array}$ & $\begin{array}{l}0.204 \\
(0.561)\end{array}$ \\
\hline international fields & $\begin{array}{l}-4.656 \\
(2.808)\end{array}$ & $\begin{array}{l}-0.360 \\
(1.141)\end{array}$ & $\begin{array}{l}1.141^{*} \\
(0.565)\end{array}$ \\
\hline population density & $\begin{array}{l}0.117^{* * *} \\
(0.030)\end{array}$ & $\begin{array}{l}0.106^{* * *} \\
(0.030)\end{array}$ & $\begin{array}{l}0.110^{* * * *} \\
(0.031)\end{array}$ \\
\hline rough terrain & $\begin{array}{l}-9.235 \\
(6.583)\end{array}$ & $\begin{array}{l}-11.488 \\
(6.706)\end{array}$ & $\begin{array}{l}-10.793 \\
(6.623)\end{array}$ \\
\hline excluded groups & $\begin{array}{l}0.327 \\
(0.241)\end{array}$ & $\begin{array}{l}0.232 \\
(0.234)\end{array}$ & $\begin{array}{l}0.571^{*} \\
(0.251)\end{array}$ \\
\hline per capita GDP & $\begin{array}{l}0.297 \\
(0.211)\end{array}$ & $\begin{array}{l}0.394 \\
(0.215)\end{array}$ & $\begin{array}{l}0.222 \\
(0.240)\end{array}$ \\
\hline spatial lag & $\begin{array}{l}1.148 \\
(1.044)\end{array}$ & $\begin{array}{l}1.146 \\
(1.047)\end{array}$ & $\begin{array}{l}0.981 \\
(1.072)\end{array}$ \\
\hline Insecure property rights & $\begin{array}{l}-0.011 \\
(0.019)\end{array}$ & & \\
\hline Insecure pr $\mathrm{x}$ state fields & $\begin{array}{l}-0.004 \\
(0.040)\end{array}$ & & \\
\hline Insecure pr $\mathrm{x}$ international fields & $\begin{array}{l}0.086^{*} \\
(0.042)\end{array}$ & & \\
\hline Semidemocracies & & $\begin{array}{l}0.155 \\
(0.551)\end{array}$ & \\
\hline Semidemocracies $\mathrm{x}$. state fields & & $\begin{array}{l}-1.702 \\
(0.996)\end{array}$ & \\
\hline Semidemocracies $\mathrm{x}$ international fields & & $\begin{array}{l}1.537 \\
(1.221)\end{array}$ & \\
\hline Polity4 & & & $\begin{array}{l}0.216^{* *} \\
(0.074)\end{array}$ \\
\hline Polity4 x state fields & & & $\begin{array}{l}-0.176 \\
(0.125)\end{array}$ \\
\hline Polity $4 \mathrm{x}$ international fields & & & $\begin{array}{l}-0.251^{*} \\
(0.118)\end{array}$ \\
\hline Variance (Intercept) & $\begin{array}{l}0.924^{* *} \\
(0.408)\end{array}$ & $\begin{array}{l}1.020^{* * * *} \\
(0.411)\end{array}$ & $\begin{array}{l}1.494^{* * * *} \\
(0.553)\end{array}$ \\
\hline LR test $\mathrm{p}$ value & 0.0000 & 0.0000 & 0.0000 \\
\hline Observations & 1314 & 1464 & 1464 \\
\hline Number of groups & 17 & 17 & 17 \\
\hline
\end{tabular}

NOTE: Two-level mixed-effects logit models with random intercept. State repression as dependent variable.

Standard errors in parenthesis ${ }^{*} \mathrm{p}<0.05,{ }^{* *} \mathrm{p}<0.01,{ }^{* * *} \mathrm{p}<0.001$.

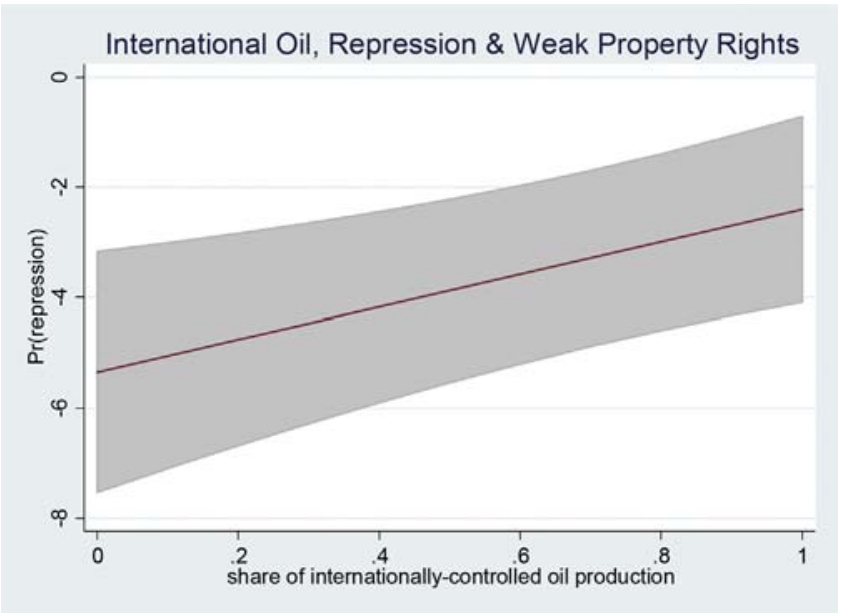

Graph. 1. Marginal Effect of Internationally-controlled hydrocarbon production on government repression under weak property rights enforcement.

weak property rights protection (Graph 1). In contrast, interna tional hydrocarbon companies do not affect the risk of repression

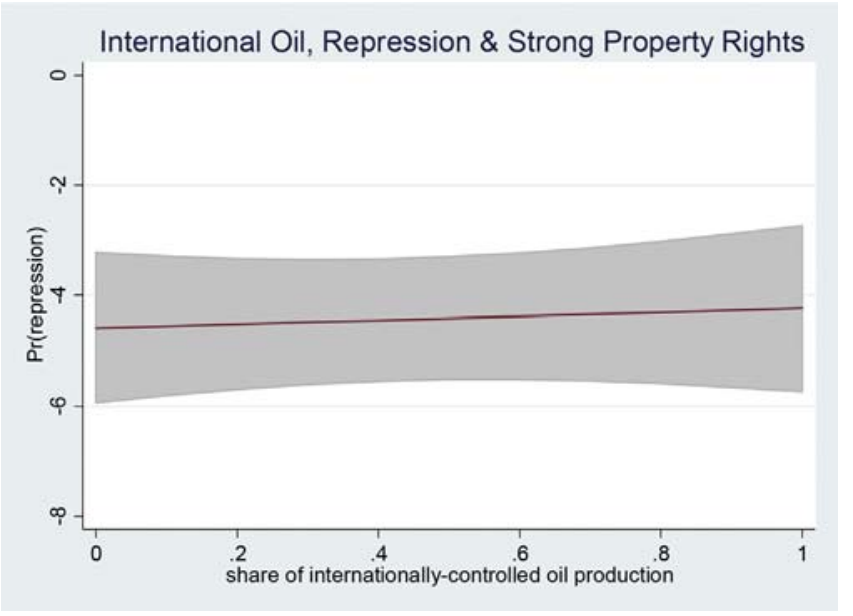

Graph. 2. Marginal Effect of Internationally-controlled hydrocarbon production on government repression under moderate or strong property rights enforcement.

under moderate or strong levels of property rights enforcement (Graph 2). 


\section{Conclusion}

Previous studies have shown that minor or major forms of intrastate conflict are often triggered by local grievances over the exploitation of natural resources. This article sheds light on an important determinant of resource related conflict that so far has been neglected by the literature: resources ownership structures. It explores the political economy of natural resources and in partic ular the role that public and international ownership plays for intrastate social conflict. Ross (2012) claims that public ownership of oil increases the risk of violence as it makes governments more dependent on the volatility of oil markets. Hodges (1995: 1305) maintains that mineral rich developing states plagued by envi ronmental degradation may in fact benefit from "reforming gov ernment policy to encourage foreign investment in resources." It is maintained that foreign firms are better suited to overcome structural barriers that prevent the adoption of cleaner technolo gies. In a similar vein, organizations such as the World Bank or the International Monetary Fund promoted the privatization of the mineral sectors in many African states in the 1990s (Craig, 2001).

Our analysis, however, indicates that resistance of local forces is particularly triggered by activities of international investors. Assuming that state violence against civilians is often a response to increased protests, riots or strikes by local communities living close to resource extraction areas, our findings show that grids hosting oil and gas fields operated by international companies experience a higher risk of suffering from government repression compared to grids with state controlled hydrocarbon production. We argue that the employment of foreign workers by international firms, anti imperialist feelings against foreign corporations and limited time horizons faced by international mining or oil investors may explain our findings.

Analyzing the conditions under which internationally controlled resource extracting firms promote social conflict, we find that economic and political uncertainty play an important moderating role. Our results indicate that multinational oil com panies are particularly likely to increase state repression when facing limited time horizons due to states' weak property rights enforcement. Fearing non compliance with negotiated contract obligations, companies are less likely to engage in a dialogue with stakeholders and less concerned with the environmental impacts of their activities or with providing basic infrastructure to the local population. In contrast, international oil companies seem to reduce social conflicts such as government repression when operating under stable, fully democratic regimes. These findings stress that when studying resource related social conflict it is important to consider how states regulate the access to their natural resources and under what institutional environment resource extraction is pursued.

We admit that the channels linking resource control rights re gimes to social conflict are still poorly understood. Our article's main aim was to find empirical evidence for the role of resource ownership structure on minor forms of intrastate violence. Future research should test the impact of ownership structures on the various forms of resource related grievances in greater detail. Moreover, it should identify unambiguous causal mechanisms on how local ownership arrangements and the national level rule of law foster intrastate violence.

\section{Funding}

Financial support from the German Research Foundation (DFG), as part of the research project "Resource Management and Intra state Conflict" (WE 4850/1 2), is gratefully acknowledged.

\section{APPENDIX}

Table A1

Effect of hydrocarbon control rights on government repression at grid level, 19972014.

\begin{tabular}{|c|c|c|c|c|}
\hline & (1) & (2) & (3) & (4) \\
\hline & Oil Producing Grids & Oil Producing Grids & Oil Producing Grids & Oil Poducing Grids \\
\hline \multicolumn{5}{|l|}{ Grid-Level Variables } \\
\hline state fields & $\begin{array}{l}1.152 \\
(1.096)\end{array}$ & $\begin{array}{l}0.640 \\
(1.794)\end{array}$ & $\begin{array}{l}1.074 \\
(1.083)\end{array}$ & $\begin{array}{l}1.117 \\
(1.100)\end{array}$ \\
\hline \multirow[t]{2}{*}{ international fields } & $2.642^{* *}$ & $7.086^{* * *}$ & $3.214^{* * *}$ & $3.402^{* *}$ \\
\hline & $(0.876)$ & $(1.967)$ & $(0.910)$ & $(1.001)$ \\
\hline \multirow[t]{2}{*}{ population density } & $0.218^{* * *}$ & $0.480^{* * *}$ & $0.255^{* * *}$ & $0.250^{* * *}$ \\
\hline & $(0.062)$ & $(0.111)$ & $(0.060)$ & $(0.063)$ \\
\hline \multirow[t]{2}{*}{ rough terrain } & -7.914 & -29.177 & -8.362 & -8.292 \\
\hline & $(6.282)$ & $(26.762)$ & $(6.271)$ & $(6.238)$ \\
\hline \multirow[t]{2}{*}{ excluded groups } & 0.467 & 0.632 & 0.425 & 0.502 \\
\hline & $(0.304)$ & $(0.475)$ & $(0.270)$ & $(0.289)$ \\
\hline \multirow[t]{2}{*}{ per capita GDP } & 0.048 & 0.627 & 0.124 & 0.073 \\
\hline & $(0.285)$ & $(0.417)$ & $(0.278)$ & $(0.287)$ \\
\hline \multirow[t]{2}{*}{ spatial lag } & 0.542 & -0.208 & 0.298 & 0.284 \\
\hline & $(1.092)$ & (1.623) & $(1.075)$ & (1.107) \\
\hline \multirow[t]{2}{*}{ polity2 } & 0.058 & 0.128 & & 0.093 \\
\hline & $(0.081)$ & $(0.180)$ & & $(0.078)$ \\
\hline \multirow[t]{2}{*}{ control of corruption } & -0.012 & & & \\
\hline & $(0.025)$ & & & \\
\hline \multirow[t]{2}{*}{ fiscal capacity } & & 0.095 & & \\
\hline & & $(0.068)$ & & \\
\hline \multirow[t]{2}{*}{ political competition } & & & 0.014 & \\
\hline & & & $(0.012)$ & \\
\hline
\end{tabular}




\begin{tabular}{|c|c|c|c|c|}
\hline & (1) & $(2)$ & (3) & (4) \\
\hline & Oil Producing Grids & Oil Producing Grids & Oil Producing Grids & Oil Poducing Grids \\
\hline quality of government & & & & $\begin{array}{l}0.513 \\
(4.333)\end{array}$ \\
\hline Variance (Intercept) & $\begin{array}{l}1.465^{* *} \\
(0.631)\end{array}$ & $\begin{array}{l}2.508^{* *} \\
(1.325)\end{array}$ & $\begin{array}{l}1.785^{* * *} \\
(0.592)\end{array}$ & $\begin{array}{l}2.082^{* * * *} \\
(0.738)\end{array}$ \\
\hline LR test $p$ value & 0.0000 & 0.0000 & 0.0000 & 0.0000 \\
\hline Observations & 1010 & 519 & 1150 & 1083 \\
\hline Number of groups & 17 & 12 & 17 & 16 \\
\hline
\end{tabular}

NOTE: Two-level mixed-effects logit models with random intercept. State repression as dependent variable.

Standard errors in parenthesis ${ }^{*} \mathrm{p}<0.05,{ }^{* *} \mathrm{p}<0.01,{ }^{* * *} \mathrm{p}<0.001$.

\section{References}

Adisu, K., Sharkey, T., \& Okoroafo, S. C. (2010). The impact of Chinese investment in Africa. International Journal of Business and Management, 5(9), 19.

Alden, C. (2005). China and Africa. Survival, 47(3), 147164.

Alexeev, M., \& Conrad, R. (2009). The elusive curse of oil. Review of Economics and Statistics, 91(3), 586598.

Allison, P. (1990). Change scores as dependent variables in regression analysis. In C. C. Clogg (Ed.), Sociological methodology (pp. 93 114). Oxford, UK: Basil Blackwell.

Allison, P. (2005). Causal inference with panel data. Paper presented at the annual meeting of the American Sociological Association. Philadelphia: Marriott Hotel.

Arellano-Yanguas, J. (2011). Aggravating the resource curse: Decentralisation, mining and conflict in Peru. Journal of Development Studies, 47(4), 617638.

Arezki, R., Bhattacharyya, S., \& Mamo, N. (2015). Resource discovery and conflict in Africa: What do the data show? Centre for the Study of African Economies. University of Oxford. Working paper WPS/2015-14, 18 June.

Armony, A., \& Velásquez, N. (2015). Anti-Chinese sentiment in Latin America: An analysis of online discourse. Journal of Chinese Political Science, 20(3), 319346.

Basedau, M., \& Lay, J. (2009). Resource curse or rentier peace? The ambiguous effects of oil wealth and oil dependence on violent conflict. Journal of Peace Research, 46(6), 120.

Basedau, M., \& Pierskalla, J. (2014). How ethnicity conditions the effect of oil and gas on civil conflict: A spatial analysis of Africa from 1990 to 2010. Political Geography, 38(1), 111.

Basedau, M., \& Richter, T. (2014). Why do some oil exporters experience civil war but others do not?: Investigating the conditional effects of oil. European Political Science Review, 6(4), 549574.

Baumol, W. J., \& Oates, W. E. (1988). The theory of environmental policy. New York: Cambridge University Press.

BBC. (2011). China answers Zambian cirtics, 2011, October 11. Available at http:// www.bbc.com/news/world-asia-pacific-15168130 (accessed 10 July 2014).

BBC. (2010). Gabon oil workers strike over foreign workers, 15 April. Available at: http://news.bbc.co.uk/2/hi/8622688.stm (accessed 10 May 2016).

BBC. (2012). Sierra Leone Koidu mine: Foreigners 'holed up' after clashes, 19 December. Available at: http://www.bbc.com/news/world-africa-20781940 (accessed May 10, 2016).

Berman, N., Couttenier, M., Rohner, D., \& Thoenig, M. (2017). This mine is mine! How minerals fuel conflicts in Africa. American Economic Review, 107(6) 15641610.

Blowfield, M. (2005). Corporate social responsibility: Reinventing the meaning of development. International Affairs, 81(3), 515524.

Brautigam, D. (2009). The Dragon's Gift: The Real Story of China in Africa. New York: Oxford University Press.

Brunnschweiler, C. N., \& Bulte, E. H. (2008). Linking natural resources to slow growth and more conflict. Science, 320(5876), 616617.

Brunnschweiler, C., \& Bulte, E. (2009). Natural resources and violent conflict: Resource abundance, dependence and the onset of civil wars. Oxford Economic Papers, 61(4), 651674.

Burawoy, M. (2014). The colour of class revisited: Four decades of postcolonialism in Zambia. Journal of Southern African Studies, 40(5), 961979.

Business and Human Rights Resource Center. (2013). Africa Oil Week 2013: Oil \& gas industry must improve its respect for human rights. Available at: https://businesshumanrights.org/sites/default/files/media/documents/africa-oil-week-briefingnote-nov-2013.pdf (accessed January 10, 2017).

Che, J., \& Qian, Y. (1998). Insecure property rights and ownership of firms. The Quarterly Journal of Economics, 113(2), 467496.

Child, J. (2002). The International crisis of confidence in corporations. Academy of Management Executive, 16(3), 145147.

Cole, M. A., Elliott, Robert J. R., \& Strobl, E. (2008). The environmental performance of firms: The role of foreign ownership, training, and experience. The Ecological Economics, 65(3), 538546.

Collier, P., \& Hoeffler, A. (2012). High-value natural resources, development, and conflict: Channels of causation. In P. Lujala, \& S. A. Rustad (Eds.), High-value natural resources and peacebuilding (pp. 297 312). London: Earthscan.

Collier, P., \& Hoeffler, A. (2004). Greed and grievance in civil war. Oxford Economic Papers, 56(4), 563595.

Cook, S. J., Blas, B., Carroll, R. J., \& Sinha, S. (2017). Two wrongs make a Right: Addressing underreporting in binary data from multiple sources. Political Analysis, 25, 223240.

Cooke, Fang Lee (2014). Chinese multinational firms in Asia and Africa: Relationships with institutional actors and patterns of HRM practices. Human Resource Management, 53(6), 877896.

Costello, C. \& Grainger, C. (2015). Property rights, regulatory capture, and exploitation of natural resources. National Bureau of Economic Research. Working paper no. 20859, January.

Cotet, A. M., \& Tsui, K. K. (2013). Oil and conflict: What does the cross-country evidence really show? American Economic Journal Macroeconomics, 5(1), 4980.

Craig, J. (2001). Putting privatisation into practice: The case of Zambia consolidated copper mines limited. The Journal of Modern African Studies, 39(3), 389410.

Crush, J., Ulicki, T., Tseane, T., \& van Veuren, E. J. (2001). Undermining labour: The rise of sub-contracting in South African gold mines. Journal of South African Studies, 27(1), 531

Davis, R., \& Franks, D. M. (2014). Costs of company-community conflict in the extractive sector. Corporate Social Responsibility Initiative. Report no. 66. Cambridge: Harvard Kennedy School.

DeMeritt, J. H. R., \& Young, J. K. (2013). A political economy of human rights: Oil, natural gas, and state incentives to repress. Conflict Management and Peace Science, 30(2), 99120

Eden, L., \& Miller, S. R. (2004). Distance matters: Liability of foreignness, institutional distance and ownership strategy (s.l.). In M. A. Hitt, \& L. C. Cheng (Eds.) Theories of the multinational Enterprise: Diversity, complexity and relevance (advances in international management, volume 16) (pp. 187 221). Emerald Group Publishing Limited.

Eskeland, G. S., \& Harrison, A. E. (2003). Moving to greener pastures? Multinationals and the pollution haven hypothesis. Journal of Development Economics, 70(1), 123.

Eweje, G. (2009). Labour relations and ethical dilemmas of extractive MNEs in Nigeria, South Africa and Zambia: 1950-2000. Journal of Business Ethics, 86(2), 207223.

Farzanegan, M. R., Lessmann, C., \& Markwardt, G. (2013). Natural-resource rents and internal conflicts can decentralization lift the curse? CESifo. Working paper no. 4180, March.

Financial Times. (2013). Tullow temporarily halts Kenya work after protests, 28 October. Available at: http://www.ft.com/intl/cms/s/0/682ea95a-3fe1-11e38990-00144feabdc0.html\#axzz48pIZSxqH (accessed 10 May 2016).

Giuliani, E., \& Macchi, C. (2013). Multinational corporations' economic and human rights impacts on developing. Cambridge Journal of Economics, 38(2), 132.

Gordon, T., \& Webber, J. R. (2008). Imperialism and resistance: Canadian mining companies in Latin America. Third World Quarterly, 29(1), 6387.

Gurr, T. R., Jaggers, K., \& Moore, W. (1989). Polity II handbook. Boulder: University of Colorado Press.

Guriev, S., Kolotilin, A., \& Sonin, K. (2011). Determinants of nationalization in the oil sector: A theory and evidence from panel data. The Journal of Law, Economics and Organization, 27(2), 301323.

Haber, S., \& Menaldo, V. (2010). Do natural resources fuel authoritarianism? A reappraisal of the resource curse. American Political Science Review, 105(1), 126.

Haslam, P. A., \& Tanimoune, N. A. (2016). The determinants of social conflict in the Latin American mining sector: New evidence with quantitative data. World Development, 78, 401419

Hodges, C. A. (1995). Mineral resources, environmental issues, and land use. Science, 268, 13051312.

Hox, J. J. (2010). Multilevel Analysis: Techniques and applications. New York: Routledge.

Humphreys, M. (2005). Natural resources, conflict and conflict resolution. Journal of Conflict Resolution, 49(4), 508537. 
Infomine. (2013). Mine sites: Major mining operations around the world. Available at: http://www.infomine.com/minesite/ (accessed 20 August 2013).

Karl, T. L. (1997). The paradox of Plenty: Oil booms and petro-states. Berkeley: University of California Press.

Kennedy, R., \& Tiede, L. (2011). Nationalization in the oil sector: A political economy perspective. Annual Meeting of the International Studies Association Annual Conference, 16 March 2011, Montreal, Canada. Available at: http://www. allacademic.com/meta/p502504 index.html (accessed 3 August 2013).

Kohl, B., \& Farthing, L. (2012). Material constraints to popular imaginaries: The extractive economy and resource nationalism in Bolivia. Political Geography, 31, 225235.

Kotschwar, B., Moran, T., \& Muir, J. (2011). Do Chinese mining companies exploit more? Americas Quarterly. Fall 2011.

Koubi, V., Spilker, G., Bohmelt, T., \& Bernauer, T. (2014). Do natural resources matter for interstate and intrastate armed conflict? Journal of Peace Research, 51(2), 227243.

Le Billon, P. (2008). Diamond wars? Conflict diamonds and geographies of resource wars. Annals of the Association of American Geographers, 98(2), 345372.

Lee, C. K. (2009). Raw encounters: Chinese managers, african workers and the politics of casualization in Africa's Chinese enclaves. China Quarterly, 199, 647666.

Lei, Yu-H., \& Michaels, G. (2014). Do giant oilfield discoveries fuel internal armed conflicts? Journal of Development Economics, 110, 139157.

London Mining Network. (2010). Rio Tinto: A shameful history of human and labour rights abuses and environmental degradation around the globe, 20 April. Available at: http://londonminingnetwork.org/2010/04/rio-tinto-a-shameful-history-ofhuman-and-labour-rights-abuses-and-environmental-degradation-aroundthe-globe/ (accessed 20 July 2014)

Long, N. V. (1975). Resource extraction under the uncertainty about possible nationalization. Journal of Economic Theory, 10(1), 4253.

Ludwig, M. (2012). The visible hand: National oil companies, oil supply and the emergence of the hotelling rent. WWZ, University of Basel. Discussion paper 2012/11, July.

Lujala, P. (2010). The spoils of nature: Armed civil conflict and rebel access to natural resource. Journal of Peace Research, 47(1), 1528.

Lujala, P. (2009). Deadly combat over natural resources. Journal of Conflict Resolution, 53(1), 5071.

Lujala, P., Petter Gleditsch, N., \& Gilmore, E. (2005). A diamond curse? Civil war and a lootable resource. Journal of Conflict Resolution, 49(4), 538562.

Luong, P. J., \& Weinthal, E. (2010). Oil is not a Curse: Ownership structure and institutions in soviet successor states. New York: Cambridge University Press.

Mandy, B. (1999). The role and responsibility of oil multinationals in Nigeria. Journal of International Affairs, 53(1), 281301

Manzano, O., \& Monaldi, F. (2010). The political economy of oil contract renegotiation in Venezuala. In W. Hogan, \& F. Sturzenegger (Eds.), The natural resources Trap: Private investment without public commitment (pp. 409 465). Cambridge: MIT Press.

Mehlum, H., Moene, K., \& Torvik, R. (2006). Institutions and the resource curse. Economic Journal, 115(508), 120.

Mohan, G. (2013). Beyond the enclave: Towards a critical political economy of China and Africa. Development and Change, 44(6), 12551272.

Mommer, B. (1996). Integrating the oil: A structural analysis of petroleum in the venezuelan economy. Latin American Perspectives, 23(3), 132158.

Mususa, P. (2010). "Getting by": Life on the Copperbelt after the privatization of the zambian consolidated copper mines. Social Dynamics, 36(2), 380394.

Nordhaus, W. D. (2006). Geography and macroeconomics: New data and new findings. PNAS, 103(10), 35103517.

Obi, C. I. (2010). Oil extraction, dispossession, resistance, and conflict in Nigeria's oil-rich Niger Delta. Canadian Journal of Development Studies, 30(1 2), 219236.

Oneal, J. R., \& Oneal, F. H. (1988). Hegemony, imperialism, and the profitability of foreign investments. International Organization, 42(2), 347373.

O'Reilly, C., \& Murphy, R. H. (2015). Do economic and political institutions mitigate the risk of natural resource conflicts?. Report, 7 September. Available at: http:/| papers.ssrn.com/sol3/papers.cfm?abstract_id 2572761 (accessed 11 January 2016).

Patey, L. A. (2012). Lurking beneath the surface: Oil, environmental degradation, and armed conflict in Sudan. In P. Lujala, \& S. A. Rustad (Eds.), High-value natural resources and peacebuilding (pp. 563 570). London: Earthscan.

Platform. (2014). Reinforcing dictatorships britain's gas grab and human rights abuses in Algeria. London: Platform.

Ploeg, F. van der, \& Rohner, D. (2012). War and natural resource exploitation. European Economic Review, 56, 17141729.

Poe, S. C. (2004). The decision to repress: An integrative theoretical approach to research on human rights and repression. In S. Carey, \& S. Poe (Eds.), Understanding human rights Violations: New systematic studies. Ashgate Publishing.

Porter, G. D. (2013). The new resource regionalism in North Africa and the sahara. SciencePo Centre de Recherches Internationales. Available at: http://www. sciencespo.fr/ceri/fr/content/dossiersduceri/new-resource-regionalism-northafrica-and-sahara.

Reinhardt, F. (1999). Market failure and the environmental policies of firms. Journal of Industrial Ecology, 3(1), 921.

Revenue Watch Institute. (2013). Resource governance index. Report. Available from: http://www.revenuewatch.org/sites/default/files/rgi_2013_Eng.pdf (accessed 2 August 2013).

Robinson, J. A., Torvik, R., \& Verdier, T. (2006). Political foundations of the resource curse. Journal of Development Economics, 79(2), 447468.

Ross, M. L. (2003). The natural resource curse: How wealth can make you poor. In I. Bannon, \& P. Collier (Eds.), Natural resources and violent conflict (pp. 17 42). Oxford: Oxford University Press.

Ross, M. (2006). A closer look at oil, diamonds, and civil war. Annual Review of Political Science, 9, 265300.

Ross, M. L. (2012). The oil Curse: How petroleum wealth shapes the development of nations. Princeton: Princeton University Press.

Ross, M. L. (2015). What have we learned about the resource curse? Annual Review of Political Science, 18, 239259

Salehyan, I., Hendrix, C. S., Hamner, J., Case, C., Linebarger, C., Stull, E., et al. (2012). Social conflict in Africa: A new database. International Interactions, 38(4), 503511.

Shaker, F. (1970). The multinational corporation: The new imperialism. November December Columbia Journal of World Business, 8084.

Smith, B. (2004). Oil wealth and regime survival in the developing world, 19601999. American Journal of Political Science, 48(2), 232246.

Smith, B. (2015). Resource wealth as rent leverage: Rethinking the oil stability nexus. Epub ahead of print 3 November Conflict Management and Peace Science, 2015. http://dx.doi.org/10.1177/0738894215609000.

Snyder, R., \& Bhavnani, R. (2005). Diamonds, blood, and taxes: A revenue-centered framework for explaining political order. Journal of Conflict Resolution, 49(4), 563597.

Sorens, J. (2011). Mineral production, territory, and ethnic rebellion: The role of rebel constituencies. Journal of Peace Research, 48(5), 571585.

de Soysa, I., \& Binningsbø, H. M. (2009). Devil's excrement or social cement? Oil wealth and repression, 1980 2004. International Social Science Journal, 57(1), 2132.

de Soysa, I., \& Nordås, R. (2007). Islam's bloody innards? Religion and political terror, 1980 2000. International Studies Quarterly, 51(4), 927943.

Spiegel Online International. (2010, December 9). Investment with strings attached: Cables reveal resentment at Chinese influence in Africa. Available at: http://www. spiegel.de/international/world/investment-with-strings-attached-cablesreveal-resentment-at-chinese-influence-in-africa-a-733870.html (accessed 15 November 2015)

Teorell, J., Charron, N., Dahlberg, S., Holmberg, S., Rothstein, B., Sundin, P., et al. (2013). The quality of government dataset. version 20Dec13. University of Gothenburg: The Quality of Government Institute.

The Atlantic. (2011, November 29). Is a U.S. mining company funding a violent crackdown in Indonesia?. Available at: http://www.theatlantic.com/ international/archive/2011/11/is-a-us-mining-company-funding-a-violentcrackdown-in-indonesia/249164/ (accessed 13 November 2015).

The Atlantic. (2013). Ghana's gold-mine arrest, China's latest headache in Africa, 10 June. Available at: http://www.theatlantic.com/china/archive/2013/06/ghanasgold-mine-arrest-chinas-latest-headache-in-africa/276707/ (accessed 10 June 2016)

The East African. (2013). Mtwara protests expose gaps in oil, gas, mineral laws management. February 2. Available at: http://www.theeastafrican.co.ke/news/ Mtwara-protests-expose-gaps-in-oil-gas-mineral-laws-management/-/2558/ 1682724/-/item/0/-/43axygz/-/index.html (accessed 10 January 2017).

The Economist. (2011). The Chinese in Africa: Trying to pull together, 20 April. Available at: http://www.economist.com/node/18586448 (accessed 2 August 2013).

The Guardian. (2007, January 16). Iraqis will never accept this sellout to the oil corporations. Available at: http:/www.theguardian.com/commentisfree/2007/jan/ 16/comment.iraq (accessed 10 January 2016).

The Guardian. (2011, 3 October). Shell oil paid Nigerian military to put down protests, court documents show. Available at: http://www.theguardian.com/world/2011/ oct/03/shell-oil-paid-nigerian-military (accessed 13 May 2016).

The Guardian. (2014, July 19). Killings at UK-owned Tanzanian gold mine alarm MPs. Available at: http://www.theguardian.com/world/2014/jul/19/killings-ukowned-gold-mine-tanzania-concern (accessed 17 May 2016).

The Guardian. (2015, 10 February). British gold mining firm agrees settlement over death of Tanzanian villagers. Available at: http://www.theguardian.com/ environment/2015/feb/10/british-gold-mining-settlement-deaths-tanzanianvillagers (accessed 17 May 2016).

The New York Times. (2002). Nigerian women, in peaceful protest, shut down oil plant, 14 July. Available at: http://www.nytimes.com/2002/07/14/world/ nigerian-women-in-peaceful-protest-shut-down-oil-plant.html (accessed 10 May 2016).

The New York Times. (2013, September 17). China finds resistance to oil deals in Africa. Available at: http://www.nytimes.com/2013/09/18/world/africa/chinafinds-resistance-to-oil-deals-in-africa.html?pagewanted 1\& $\mathrm{r} 0$ (accessed 7 January 2014).

The New Yorker. (2013, June 12). China in Africa: The New Imperialists?. Available at: http://www.newyorker.com/news/news-desk/china-in-africa-the-newimperialists (accessed 15 June 2016)

Thies, C. (2010). Of rulers, rebels, and revenue: State capacity, civil war onset, and primary commodities. Journal of Peace Research, 47(3), 321332.

Tollefsen, A. F., Strand, H., \& Buhaug, H. (2012). PRIO-grid: A unified spatial data structure. Journal of Peace Research, 49(2), 363374.

Torvik, R. (2001). Learning by doing and the Dutch disease. European Economic Review, 45(2), 285306

Torvik, R. (2002). Natural resources, rent-seeking and welfare. Journal of Development Economics, 67(2), 455470. 
U.S. Geological Survey. International minerals statistics and information 2013. Report. Available at: http://minerals.usgs.gov/minerals/pubs/country/index. html\#pubs (accessed 20 August 2013).

Ukeje, C. (2001). Oil communities and political violence: The case of ethnic Ijaws in Nigeria's Delta Region. Terrorism and Political Violence, 13(4), 1536.

Van der Ploeg, F., \& Poelhekke, S. (2017). The impact of natural Resources: Survey of recent quantitative evidence. The Journal of Development Studies, 53(2), 205216.

Warenfels, I. (2002). Obstacles to privatisation of state-owned industries in Algeria: The political economy of a distributive conflict. The Journal of North African Studies, 7(1), 128.

Wegenast, T. (2013). Opening pandora's box? Inclusive institutions and the onset of internal conflict in oil-rich countries. International Political Science Review,
34(4), 392410

Wegenast, T. (2016). Oil, natural gas, and intrastate Conflict: Does ownership matter? International Interactions, 42(1), 3155.

Wegenast, T., \& Basedau, M. (2014). Ethnic fractionalization, natural resources and armed conflict. Conflict Management and Peace Science, 31(4), 432457.

Wucherpfennig, J., Weidmann, N. B., Girardin, L., Cederman, L. E., \& Wimmer, A. 2011). Politically relevant ethnic groups across space and time: Introducing the GeoEPR dataset. Conflict Management and Peace Science, 28(5), 423437.

Zaheer, S. (1995). Overcoming the liability of foreignness. Academy of Management Journal, 38(2), 341363.

Zarsky, L. (1999). Havens, halos and spaghetti: Untangling the relationship between FDI and the environment. In Foreign direct investment and the environment (pp. 47 73). Paris: OECD. 